\title{
Fish fauna and the population of a Korean endangered freshwater fish, Brachymystax lenok tsinlingensis, in Korea: Bonghwa Habitat
}

\author{
Dohun Lim', Yoonjin Lee $^{2^{+}}$ \\ ${ }^{1}$ Korea Natural Environment Institute, 414, Sungsa, Dukyanggu, Goyang 10465, Republic of Korea \\ ${ }^{2}$ Department of General Education, Konyang University, Daejeon 35365, Republic of Korea
}

\begin{abstract}
This research was an evaluation of the fish fauna and the habitat for Brachymystax lenok tsinlingensis (B. lenok tsinlingensis) for 11 stations at the Bonghwa-gun sanctuary. The predominant species in this research area was Zacco koreanus. B. lenok tsinlingensis, which has been designated as an endangered freshwater fish in Korea, was found in the Bonghwa sanctuary zone, except at stations 5 and 6 . The B. lenok individuals were shorter in length than $400 \mathrm{~mm}$. In total, 13 endemic species were found, including Coreoleuciscus splendidus and Iksookimia longicorpus. Specimens of Koreocobitis naktongensis, a first grade endangered species, were also collected. The benthic macroinvertebrates consisted of four divisions, four classes, seven orders, 30 families, 60 species, and 10,344 individuals and were distributed among the orders Ephemeroptera $(55.9 \%)$, Diptera $(18.2 \%)$, Trichoptera $(12.4 \%)$, Plecoptera $(2.1 \%)$, and Odonata $(0.3 \%)$.
\end{abstract}

Keywords: Brachymystax lenok tsinlingensis, Dominant species, Habitat environment, Migration, Threatened species

\section{Introduction}

Brachymystax lenok tsinlingensis (B. lenok tsinlingensis) is a cold-water fish that inhabits areas of Northeastern Asia, including Siberia, the Maritime Province, Heilong Jiang, and the Songhua, Amnok, and Tumen rivers [1, 2]. It is managed in natural monuments in Korea established to preserve a number of fish species because of recent declines in its population. The habitat has also been disturbed by the development of mountain areas and road construction. The main reason for the decrease in $B$. lenok tsinlingensis in China has been illegal overfishing with electric shocks [3].

The Bonghwa sanctuary is recognized as the southern limit of the B. lenok habitat. However, this habitat was destroyed and the streams were polluted by waste released from mining enterprises in the 1960s. B. lenok was designated in 2012 as a protected wildlife species in Korea [4].

$B$. lenok lives in mountain streams containing clean and low temperature water (below $20^{\circ} \mathrm{C}$ ) with dissolved oxygen (DO) of $10 \mathrm{mg} / \mathrm{L}$. Its ground color is yellowish brown, with a midnight blue dorsal color and a silver white ventral color. Young fish have about 10 blackish brown cross striations on the sides of the body. Tiny dark brown spots are scattered on the sides of body and back. The lengths of the lower and upper jaws are almost the same.

Jean [5] concluded that the scientific name was B. lenok tsinlingensis, after a comparison of the morphological characteristics, such as the lateral spots, the pyloric caeca, etc., for the corrected domestic lenok endemic to the upper region of the Han River. Byeon [6] assessed B. lenok tsinlingensis with lengths of 80-180 $\mathrm{mm}, 200-300 \mathrm{~mm}$, and over $300 \mathrm{~mm}$ as being 1 year, 2 years, and 3 years old, respectively. Yoon and Jang [7], who observed the daily movements of $B$. lenok tsinlingensis in the upper part of the Nakdong River, concluded that these fish move $8.6 \mathrm{~m}$ per $\mathrm{d}$ and migrate pool to pool during the winter period, whereas they move $96.2 \mathrm{~m}$ per day in the spawning season [7].

This study assessed the $B$. lenok habitat, fish fauna, and benthic macroinvertebrate fauna of the Bonghwa sanctuary area. The purpose of the research was to determine the existing fish species
This is an Open Access article distributed under the terms of the Creative Commons Attribution Non-Commercial License (http://creativecommons.org/licenses/by-nc/3.0/) which permits unrestricted non-commercial use, distribution, and reproduction in any medium, provided the original work is properly cited.

Copyright (C) 2019 Korean Society of Environmental Engineers
Received October 5, 2018 Accepted December 31, 2018

${ }^{\dagger}$ Corresponding author

Email: leeyj@konyang.ac.kr

Tel: +82-42-600-8660 Fax: +82-42-600-8660

ORCID: 0000-0003-0851-675X 
distribution, the population of $B$. lenok tsinlingensis, and the growth conditions for $B$. lenok tsinlingensis. The ecological conditions in the habitat at the sanctuary area and the neighboring watershed were also evaluated. The overall aim was to supply basic data for assessment of the current habitat situation and for formulating future conservation plans that consider the conditions required to support food organisms and the water environment for $B$. lenok tsinlingensis.

\section{Materials and Methods}

\subsection{Water Quality}

The investigation area for this research was located in and around the natural monument of Bonghwa-gun, Gyeongsangbuk-do in Korea. The research area included the Sonjeongri and Byeongo streams, a branch of the Sonjeongri stream, and the Nakdong River. The Bonghwa-gun area has an annual mean temperature of $12.9^{\circ} \mathrm{C}$, mean precipitation of $1,282.6 \mathrm{~mm}$, and mean wind velocity of $2.7 \mathrm{~m} / \mathrm{s}$. No wastewater treatment plants are located around the $B$. lenok habitat in Bonghwa.

The water $\mathrm{pH}$, temperature, conductivity, and DO were analyzed with a YSI 556 multiprobe system (YSI Environmental, Yellow Springs, OH, USA) at each station. The suspended solid (SS), biochemical oxygen demand (BOD), and total nitrogen (TN) were measured using the official standard analytical methods for water quality in Korea after water samples from each sampling site were transferred to laboratory.

\subsection{Sampling and Analysis}

Fish were sampled and analyzed from the 11 sampling sites indicated in Fig. 1. The experiments were performed three times, from Sep., 2015 to Apr., 2016. 2 sites were selected for the Nakdong River, 4 sites for the Byeongocheon stream, and 5 sites for the Songjeongri stream to evaluate the influence of each water system. The analyses considered the variations due to season by sampling in the summer (Sep., 2015), fall (Nov., 2015), and spring (Apr., 2016). Water analysis was performed at 6 sites to evaluate the environment of the $B$. lenok habitat in the Bonghwa natural monument area and the branches of neighboring streams. Water samples were collected at the Stations 2, 3, 6, 7, 8, and 11 .

$B$. lenok specimens were collected with a cast net (mesh size: $6 \mathrm{~mm} \times 6 \mathrm{~mm}$ ) and skimming net (mesh size: $5 \mathrm{~mm} \times 5 \mathrm{~mm}$ ) to evaluate the growth state. The fish were identified using a classification table and illustrated book [8-13], following the classification described by Nelson [14].

The species diversity index [15-16] were assessed to analyze the $B$. lenok communities in the research areas. Two species, selected in accordance with the population standing crop, were assessed using McNaughton's dominance index [17].

The relationship of total length to weight was compared for the $B$. lenok specimens from each site to determine the state of growth and reproductive capacity. The growth rate and degree of obesity can provide information about the habitat compatibility, food-use capability, and water quality [18-19].

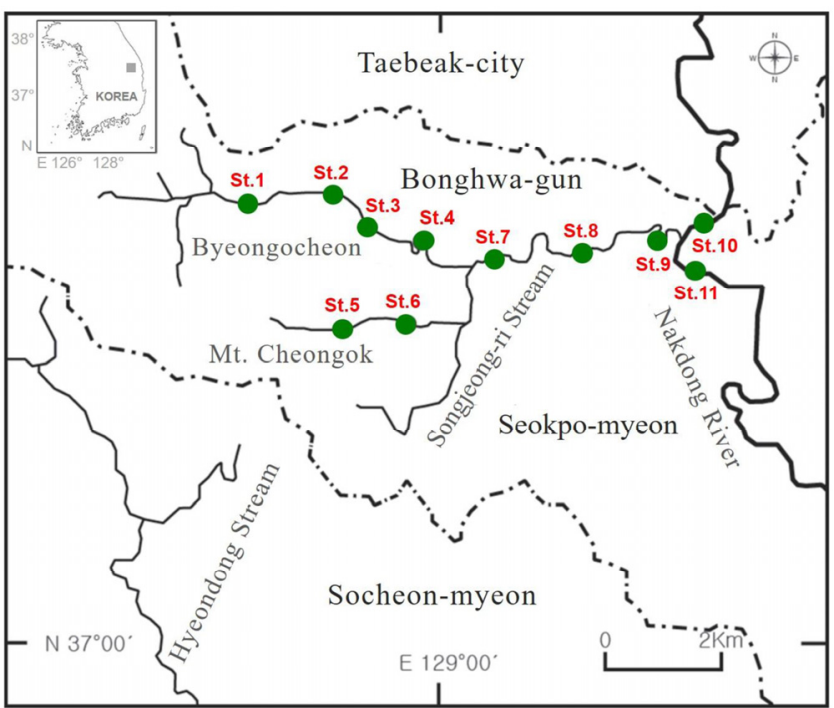

Fig. 1. Sampling stations in this study.

\section{Results and Discussion}

\subsection{Environmental Conditions}

An area of 24,232,086 $\mathrm{m}^{2}$ at the Bonghwa sanctuary is currently protected as a national monument for the habitat of $B$. lenok in Korea. However, development pressure has recently increased around this area, necessitating suitable management plans for conservation of the $B$. lenok population and its habitat. For this purpose, the fish distributions in the sanctuary and in the neighboring area were monitored with respect to water temperature and the presence of prey organisms. The mean altitude in this area is $980 \mathrm{~m}$ and slope in most of the sanctuary area is between $20^{\circ}$ and $40^{\circ}$, which is a sharp slant; only $0.41 \%$ of the area is flat land. The main habitat area for $B$. lenok was the Byeongo stream. Vegetation is poor in the area at the branch of the Songjeongri stream, due to a constriction of the river bank and bed. Shady spots are lacking at Stations 7, 10, and 11.

\subsection{Benthic Macroinvertebrates}

Fig. 2 shows photographs of benthic macroinvertebrates found in this area, and the seasonal variations in benthic macroinvertebrates at the stations are shown in Table 1 . The benthic macroinvertebrates found at Stations 2, 6, 7, 9, and 11 were from 4 divisions, 4 classes, 7 orders, 30 families, and 60 species, and consisted of 10,344 individuals. In this research, 60 species were found, in contrast to the results of a previous survey [20], which reported 56 species in the research stream.

Species classifications were as follows: Eight (12.7\%) were non-insect species. Insect species included Ephemeroptera (36.5\%), Trichoptera (28.6\%), Diptera (11.1\%), Plecoptera (9.5\%), and Odonata (1.6\%). The population of non-insect species included 1,144 individuals, while 5,785, 1,881, 1,285, 215, and 33 individuals were observed for the Ephemeroptera, Diptera, 


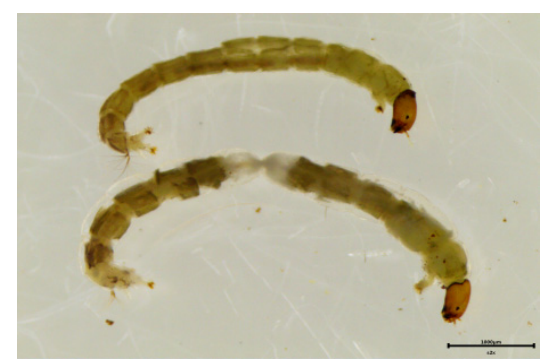

Chironomidae spp.

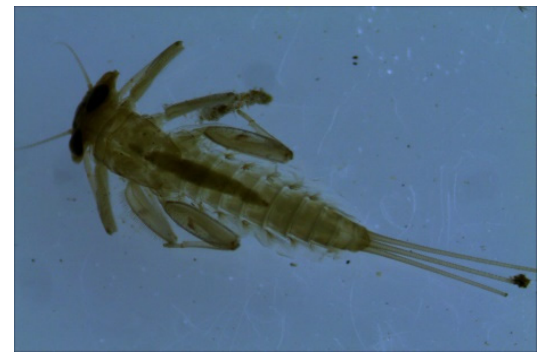

Ecdyonurus dracon

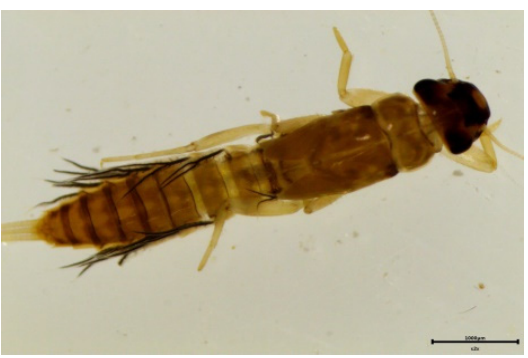

Paraleptophlebia japonica

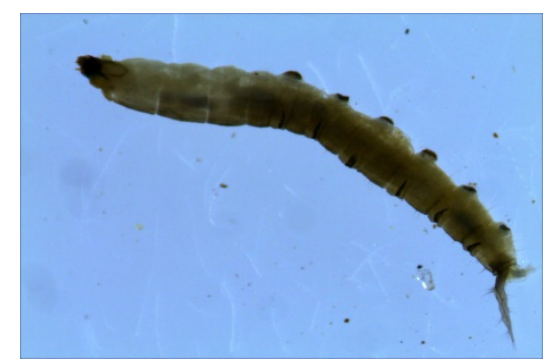

Antocha KUa

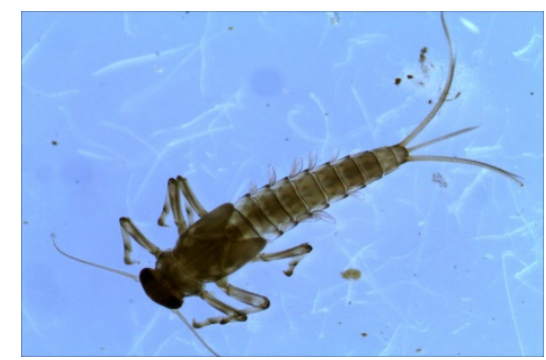

Baetis fuscatus

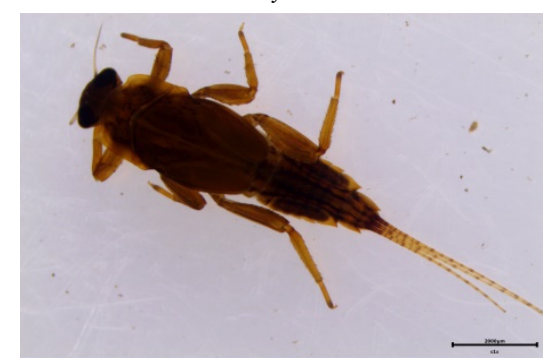

Cincticostella levanidovae

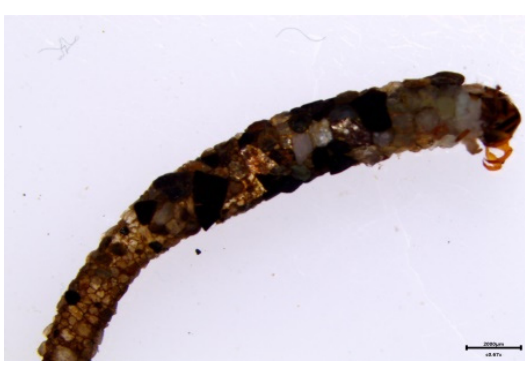

Psilotreta locumtenens

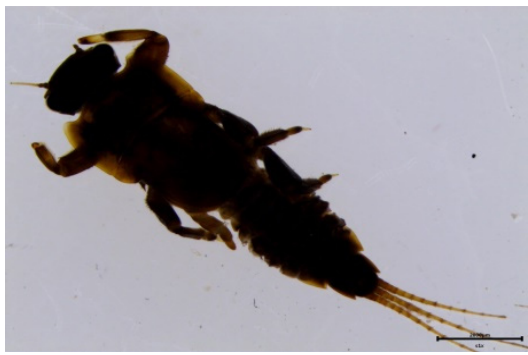

Cincticostella tshernovae

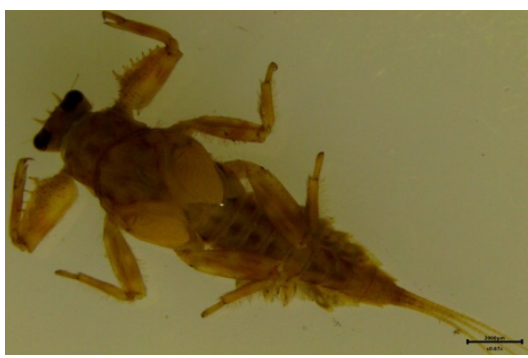

Drunella aculea

Fig. 2. Photograph of the benthic macroinvertebrates found in the research area.

Table 1. Dominant and Sub-dominant Species Analyzed at Each Station

\begin{tabular}{|c|c|c|c|c|c|c|c|}
\hline Season & Station & Dominant species / Subdominant species & DSI* & $\begin{array}{c}\text { Diversity } \\
\text { index }\end{array}$ & $\begin{array}{c}\text { Species } \\
\text { evenness }\end{array}$ & $\begin{array}{l}\text { Species } \\
\text { richness }\end{array}$ & BMI(grade) \\
\hline \multirow{5}{*}{ Sep. } & St. 2 & Ecdyonurus dracon / Baetis fuscatus & 0.42 & 2.39 & 0.84 & 2.66 & $94(\mathrm{~A})$ \\
\hline & St. 6 & Baetis fuscatus / Chironomidae spp. & 0.68 & 1.70 & 0.63 & 2.31 & $90(\mathrm{~A})$ \\
\hline & St. 7 & Limnephilus KUa / Chironomidae spp. & 0.49 & 1.97 & 0.90 & 1.89 & $90(\mathrm{~A})$ \\
\hline & St. 9 & Ecdyonurus dracon / Ephemera strigata & 0.38 & 2.30 & 0.81 & 2.41 & $90(\mathrm{~A})$ \\
\hline & St. 11 & Chironomidae spp. / Antocha KUa & 0.42 & 2.26 & 0.86 & 2.29 & $67(\mathrm{~B})$ \\
\hline \multirow{5}{*}{ Nov. } & St. 2 & Paraleptophlebia japonica / Epeorus pellucidus & 0.61 & 1.91 & 0.65 & 2.53 & $92(\mathrm{~A})$ \\
\hline & St. 6 & Drunella aculea / Hydropsyche orientalis & 0.65 & 1.82 & 0.71 & 1.94 & $95(\mathrm{~A})$ \\
\hline & St. 7 & Cincticostella levanidovae / Ephemerella setigera & 0.58 & 2.15 & 0.72 & 3.17 & $94(\mathrm{~A})$ \\
\hline & St. 9 & Paraleptophlebia japonica / Ecdyonurus dracon & 0.61 & 1.87 & 0.59 & 3.18 & 92(A) \\
\hline & St. 11 & Antocha KUa / Chaetogaster limnaei & 0.64 & 1.84 & 0.62 & 2.35 & $69(\mathrm{~B})$ \\
\hline \multirow{5}{*}{ Apr. } & St. 2 & Psilotreta locumtenens / Ephemera strigata & 0.36 & 2.33 & 0.91 & 2.36 & $96(\mathrm{~A})$ \\
\hline & St. 6 & Cincticostella tshernovae / Cincticostella levanidovae & 0.52 & 1.85 & 0.75 & 1.93 & $94(\mathrm{~A})$ \\
\hline & St. 7 & Paraleptophlebia japonica / Ecdyonurus bajkovae & 0.86 & 1.13 & 0.47 & 1.42 & $93(\mathrm{~A})$ \\
\hline & St. 9 & Paraleptophlebia japonica / Glossosoma KUa & 0.61 & 2.10 & 0.73 & 2.84 & $92(\mathrm{~A})$ \\
\hline & St. 11 & Chironomidae spp. / Semisulcospira libertina & 0.66 & 1.60 & 0.64 & 1.67 & $59(\mathrm{C})$ \\
\hline
\end{tabular}

*: Dominant Species Index 
Trichoptera, Plecoptera, and Odonata, respectively. The Ephemeroptera (55.9\%) represented the largest population.

The dominant species index ranged between 0.36 and 0.86 , with the highest value found at Station 7 in April (spring). Overall, the dominant and subdominant species in this area were the Ephemeroptera. The dominant species were Psilotreta locumtenens and Limnephilus KUa in the Trichoptera; Ecdyonurus dracon, Baetis fuscatus, Drunella aculea, Paraleptophlebia japonica, Cincticostella levanidovae, and Cincticostella tshernovae in the Ephemeroptera; and Antocha KUa and Chironomidae spp. in the Diptera. This area was thought to have a stable community structure without artificial disturbance. The benthic macroinvertebrate index (BMI) was assessed as between 59 and 96, with a biotic grade of A through B, which indicated a lack of artificial disturbance in the stream channel. However, the BMI for Station 11 was 59 at the end of April, giving it a $\mathrm{C}$ grade (i.e., a moderate environmental condition).

\subsection{Fish Fauna}

The fish encountered during this study included 9 families, 19 species, and 7,509 individuals (Table 2). B. lenok was found at all sampling points in the sanctuary area, except Stations 5 and 6 . The highest number of $B$. lenok was found at Station 3 . Koreocobitis naktongensis ( $K$. naktongensis), which is a national protected species in Korea, was also caught in this area. K. naktongensis is a species endemic to the Nakdong River and an endangered species of wild fauna. It is distributed only as an entity in the area of Station 11, with a limited habitat in Korea that includes Andong and Namwon city. Urgent management plans for this habitat are needed to preserve the $K$. naktongensis. Cottus koreanus (C. koreanus), a cold-water fish, was found at the Station 1. The sanctuary of $B$. lenok was also a habitat for $C$. koreanus. Therefore, the Bonghwa sanctuary is valuable as a habitat for $K$. naktongensis and $C$. koreanus, as well as B. lenok.

Table 2. Species and Distribution of the Collected Fish Populations

\begin{tabular}{|c|c|c|c|c|c|c|c|c|c|c|c|c|}
\hline \multirow{2}{*}{ Scientific name } & \multicolumn{11}{|c|}{ Sampling station } & \multirow{2}{*}{ Total } \\
\hline & 1 & 2 & 3 & 4 & 5 & 6 & 7 & 8 & $\mathbf{9}$ & 10 & 11 & \\
\hline \multicolumn{13}{|l|}{ Cyprinidae } \\
\hline Coreoleuciscus splendidus & & & & & & & 3 & 24 & 43 & 46 & 16 & 132 \\
\hline Microphysogobio yaluensis & & & & & & & & & & & 4 & 4 \\
\hline Pungtungia herzi & & & & & & & 1 & 17 & 12 & 3 & 1 & 34 \\
\hline Rhynchocypris oxycephalus & 43 & 503 & 591 & 291 & 724 & 104 & 15 & 86 & 4 & 113 & 228 & 2,702 \\
\hline Squalidus gracilis & & & & & & & & & 17 & 4 & 6 & 27 \\
\hline Zacco koreanus & & 28 & 12 & 147 & & 4 & 342 & 501 & 994 & 1,057 & 817 & 3,902 \\
\hline Zacco platypus & & & & & & & & & & 4 & 6 & 10 \\
\hline \multicolumn{13}{|l|}{ Cobitidae } \\
\hline Cobitis hankugensis & & & & & & & & & & 5 & & 5 \\
\hline Iksookimia longicorpus & & & & & & & & & & 26 & 12 & 38 \\
\hline Kichulchoia multifasciata & & & & & & & 5 & 2 & 24 & 7 & 25 & 63 \\
\hline Koreocobitis naktongensis & & & & & & & & & & & 1 & 1 \\
\hline \multicolumn{13}{|l|}{ Balitoridae } \\
\hline Orthrias nudus & & & & 5 & & & 1 & 2 & 3 & 4 & 5 & 20 \\
\hline \multicolumn{13}{|l|}{ Siluridae } \\
\hline Silurus microdorsalis & 4 & & 11 & 5 & & & 21 & 19 & 23 & 25 & 4 & 112 \\
\hline \multicolumn{13}{|l|}{ Amblycipitidae } \\
\hline Liobagrus mediadiposalis & & & & & & & & 1 & & & & 1 \\
\hline \multicolumn{13}{|l|}{ Salmonidae } \\
\hline Brachymystax lenok & 102 & 53 & 134 & 90 & & & 6 & 18 & 15 & 7 & 4 & 429 \\
\hline \multicolumn{13}{|l|}{ Cottidae } \\
\hline Cottus koreanus & 9 & & & & & & & & & & & 9 \\
\hline \multicolumn{13}{|l|}{ Centropomidae } \\
\hline Coreoperca herzi & & & & & & & 8 & 7 & 1 & & & 16 \\
\hline \multicolumn{13}{|l|}{ Odontobutidae } \\
\hline Odontobutis interrupta & & & & & & & & & 2 & & & 2 \\
\hline Odontobutis platycephala & & & & & & & & & 2 & & & 2 \\
\hline Family & 4 & 2 & 3 & 4 & 1 & 1 & 6 & 7 & 7 & 5 & 5 & 9 \\
\hline Species & 4 & 3 & 4 & 5 & 1 & 2 & 9 & 10 & 12 & 12 & 13 & 19 \\
\hline Population & 158 & 584 & 748 & 538 & 724 & 108 & 402 & 677 & 1,140 & 1,301 & 1,129 & 7,509 \\
\hline
\end{tabular}


Trichoptera, $11.90 \%$

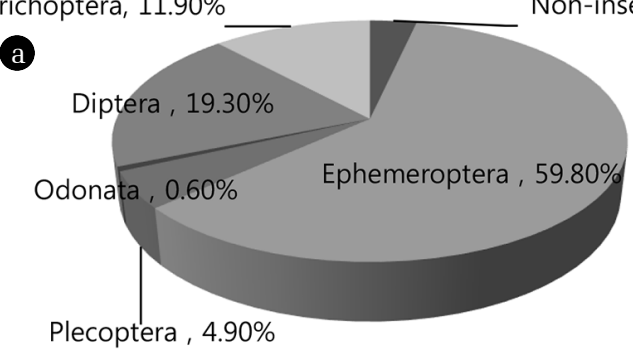

Trichoptera, $13.50 \%$

b
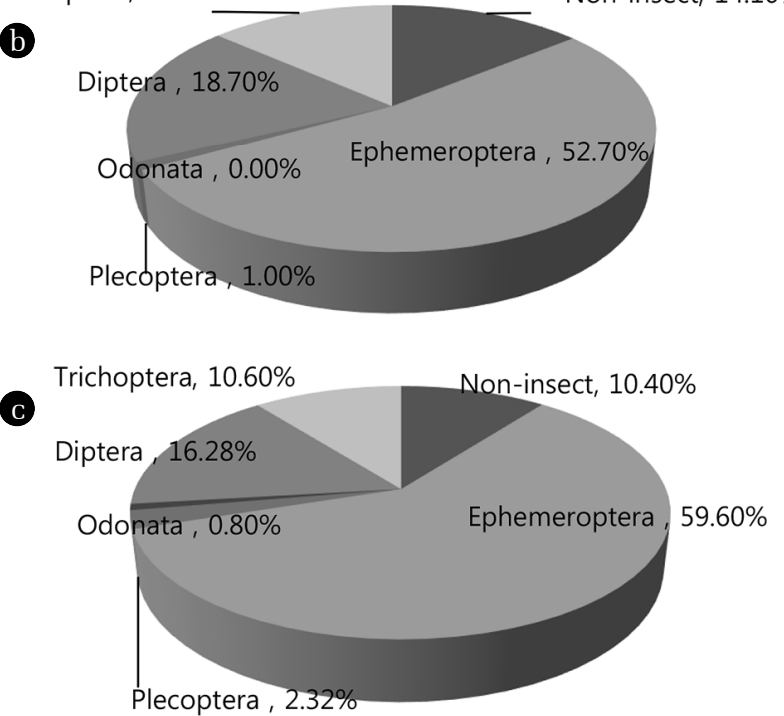

Fig. 3. Seasonal variation of the population composition of benthic macroinvertebrates in the research area. a) September, b) November, c) April.

Several endemic Korean species were found, including Coreoleuciscus splendidus (C. splendidus), Microphysogobio yaluensis (M. yaluensis), Squalidus gracilis, K. naktongensis, Silurus microdorsalis, Liobagrus mediadiposalis (L. mediadiposalis), C. koreanus, Coreoperca herzi (C. herzi), Odontobutis interrupta, and Odontobutis platycephala, with an overall percentage of $68.4 \%$. $B$. lenok was a dominant or subdominant species for the Byeongocheon stream at the Stations 1,2 and 3. Zacco koreanus (Z. koreanus) was a dominant species at Stations 7, 8, 9, 10, and 11. However, only Rhynchocypris oxycephalus (R. oxycephalus) was found at Station 5, and only Z. koreanus and $R$. oxycephalus were observed at Station 6 .

The highest number of species (1,301 individuals) appeared at Station 10. B. lenok was not found at Stations 5. However, 724 individuals of $R$. oxycephalus were found. $C$. herzi appeared at Stations 7, 8, and 9, which are along the Songjeongri stream. C. herzi is carnivorous fish that eats small fish and its presence indicated the existence of a stable food source in those environments. Species richness was highest at Station 10. Species richness was lower in the mountain stream areas than in the downstream areas.

The dominant species was Z. koreanus, in terms of relative abundance (51.96\%). The percentages of relative abundance were $35.98 \%$ for $R$. oxycephalus, $5.71 \%$ for B. lenok, $1.76 \%$ for Coreoleuciscus splendidus, and $\mathbf{1 . 4 9 \%}$ for L. mediadiposalis. Cold water species predominated in this area.

\subsection{Length-Weight Relationship}

The length of $B$. lenok did not exceed $400 \mathrm{~cm}$ in the research area (Fig. 4). Most of the $B$. lenok were under 2 years of age. The number of $B$. lenok individuals over $300 \mathrm{~mm}$ increased in April when compared to the other seasons. The B. lenok spawning season is usually in April and May, and adult fish over $300 \mathrm{~mm}$ participate in spawning. The distribution of fry under $100 \mathrm{~mm}$ was higher in the other two seasons.
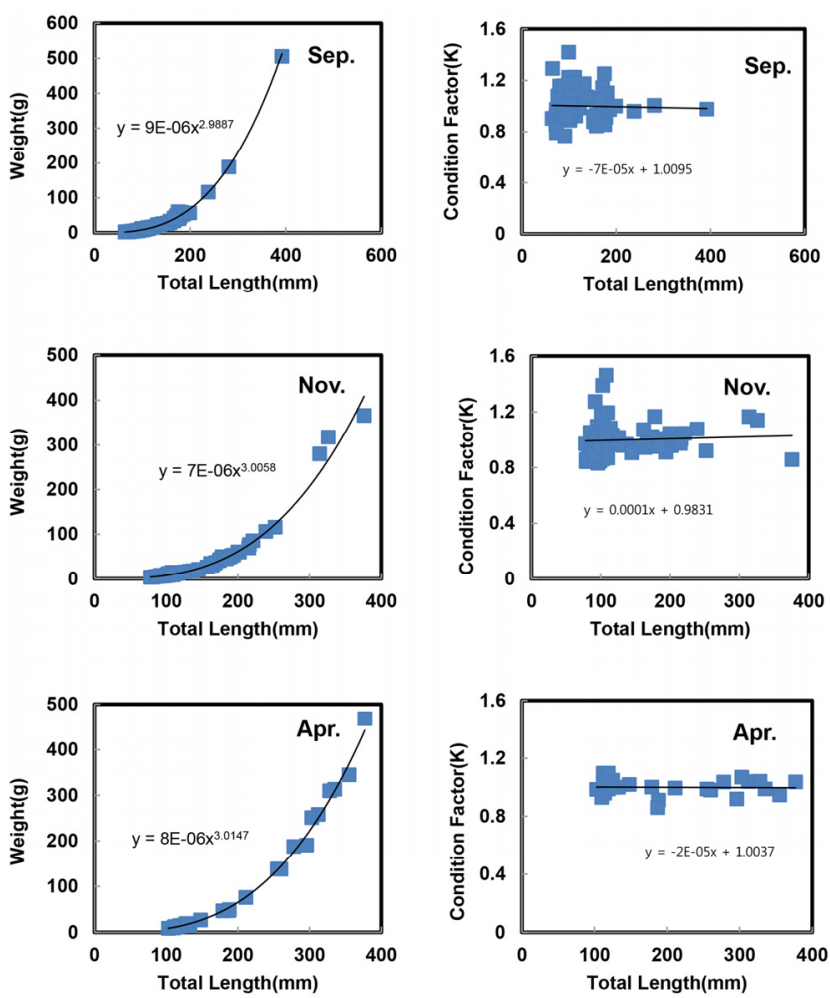

Fig. 4. Relationship between the total length and weight of Brachymystax lenok sampled seasonally in the Bonghwa sanctuary.

Generally, a value of b over 3 indicates a fair nutritional condition and the fish are growing well [21]. Values of $b$ were 2.99, 3.01, and 3.01 for Sep., Nov., Apr., respectively, in this investigation. A negative value for the degree of obesity was noted for September and April.

\subsection{Water Quality}

The data for water analysis are presented in Table 3 for Stations $2,3,6,7,8$, and 11 during the different seasons. Water temperature ranged between 0 and $19.3^{\circ} \mathrm{C}$, which generally agreed with the required temperature for a $B$. lenok habitat. The lowest level of SS occurred at Stations 2 and 3 for the B. lenok conservation area. 
Table 3. Water Quality Variations at Different Sites Sampled in This Research

\begin{tabular}{|c|c|c|c|c|c|c|c|}
\hline Items & Season & St. 2 & St. 3 & St. 6 & St. 7 & St. 8 & St. 11 \\
\hline \multirow[t]{4}{*}{ Temperature } & Apr. & 10.7 & 11.2 & 11.7 & 12.1 & 12.4 & 13.8 \\
\hline & Sep. & 15.6 & 16.4 & 16.8 & 15.0 & 19.2 & 19.3 \\
\hline & Nov. & 8.7 & 9.2 & 9.7 & 9.5 & 9.6 & 10.6 \\
\hline & Jan. & 0.0 & 0.0 & 0.0 & 0.4 & 0.0 & 1.2 \\
\hline \multirow[t]{4}{*}{ DO } & Apr. & 9.9 & 9.8 & 9.7 & 9.7 & 9.8 & 10 \\
\hline & Sep. & 8.9 & 8.5 & 9.7 & 9.7 & 8.0 & 8.1 \\
\hline & Nov. & 11.1 & 10.9 & 10.8 & 10.9 & 10.8 & 10.9 \\
\hline & Jan. & 14.4 & 14.5 & 14.4 & 14.5 & 14.6 & 15.8 \\
\hline \multirow[t]{4}{*}{ SS } & Apr. & 1.1 & 1.7 & 0.8 & 1.6 & 1.2 & 1.2 \\
\hline & Sep. & 0.6 & 0.5 & 2.1 & 0.5 & 1.4 & 2.7 \\
\hline & Nov. & 1.3 & 0.2 & 1.8 & 1.4 & 1.0 & 2.4 \\
\hline & Jan. & 0.8 & 0.3 & 0.5 & 0.7 & 1.1 & 1.2 \\
\hline \multirow[t]{4}{*}{ BOD } & Apr. & 0.77 & 0.67 & 0.72 & 0.70 & 0.71 & 1.21 \\
\hline & Sep. & 0.87 & 0.92 & 0.55 & 0.78 & 0.92 & 1.19 \\
\hline & Nov. & 0.95 & 0.55 & 0.85 & 0.90 & 0.84 & 1.31 \\
\hline & Jan. & 0.78 & 0.68 & 0.71 & 0.71 & 0.85 & 0.90 \\
\hline \multirow[t]{4}{*}{$\mathrm{T}-\mathrm{N}$} & Apr. & 1.0 & 1.1 & 0.7 & 0.8 & 0.7 & 2.2 \\
\hline & Sep. & 0.7 & 0.7 & 0.5 & 1.3 & 1.4 & 2.6 \\
\hline & Nov. & 0.8 & 0.9 & 0.9 & 1.0 & 1.0 & 3.0 \\
\hline & Jan. & 0.7 & 1.0 & 1.1 & 1.5 & 1.6 & 4.0 \\
\hline
\end{tabular}

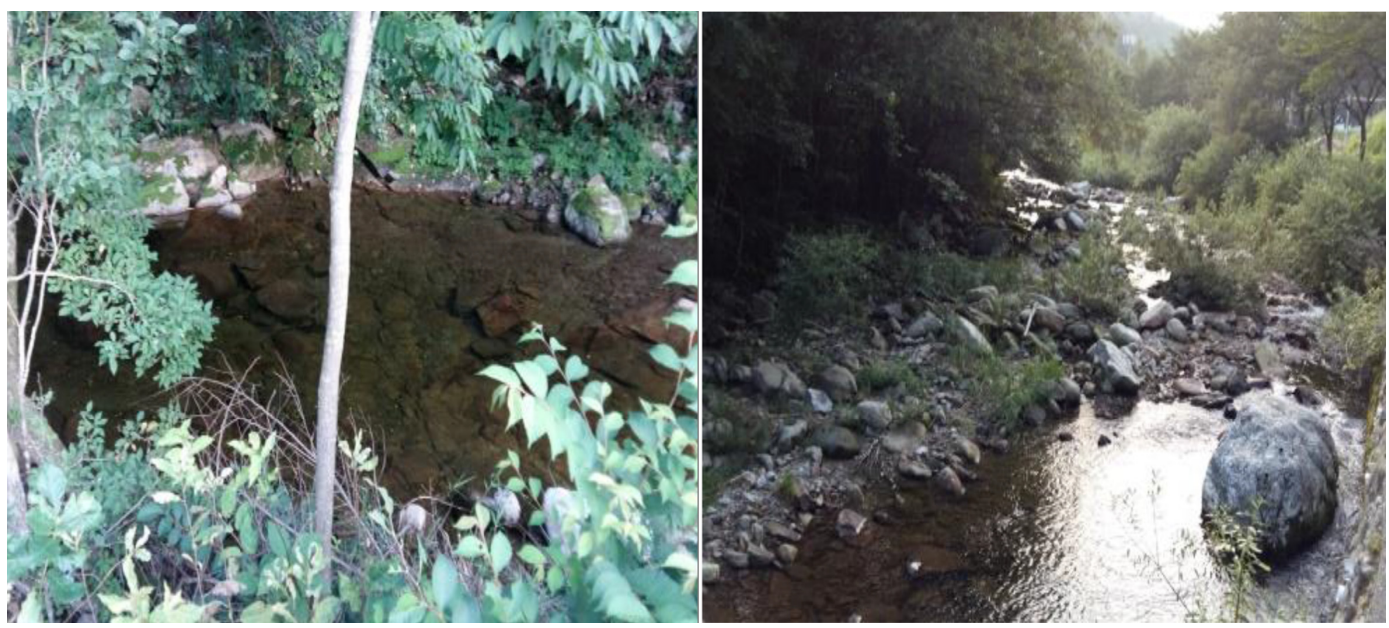

Fig. 5. Two sites where pools should be restored for the habitat of Brachymystax lenok.

The DO levels ranged between 8.0 and $15.8 \mathrm{mg} / \mathrm{L}$ and did not differ depending on the site. The highest DO level occurred in the winter. The average levels for BOD in the target area were $0.83 \mathrm{mg} / \mathrm{L}$, respectively. Station 11 had the highest levels of BOD and T-N. The water quality was graded as 'very clean' according to the environmental standard of living for streams in Korea. The water environment was optimal for a $B$. lenok habitat. However, the level of T-N increased further downstream. The level of T-N and BOD also increased after the junction with the Nakdong River.

\subsection{Conservation Plan for $B$. lenok}

Temperature should maintained annually under $20^{\circ} \mathrm{C}$ and the water deep and flow velocity fast to ensure the growth of $B$. lenok, which lives in riffles and cascades. However, two spots with existing pools in this area, indicated in Fig. 5, were buried and should be restored as fish habitats. The water temperature of the Songjeongri stream and the Nakdong River were higher than those of the designated $B$. lenok sanctuary area. The variation in temperature was temporally monitored in the area of Station 7 from April 22 to July 12, during which the seasonal temperature 
increased in this area (Fig. S1). The water temperature exceeded $20^{\circ} \mathrm{C}$ by the end of test. In this area, the only major vegetation was Phragmites japonica Steud., Salix gracilistyla, and Humulus japonicus (Fig. S2). Vegetation is poor due to the constriction of the river bed and river bank.

The highest population of $B$. lenok was found in the Byeongo stream, which is included in the sanctuary area. The main stream of the Nakdong River and the Songjeongri stream are the winter quarters of $B$. lenok. This species was not found around the branch of the Songjeongri stream (Station 5 and 6), where it was reported in 2010. The movement upstream was obstructed because several drops were installed and the water environment was damaged after construction for flood restoration. The designation of a transition zone could be an option around the stream because the Nakdong River and Songjeongri stream are crucial for the growth of $B$. lenok. An inlet of turbid water and organic matter from the neighboring sites and installment of awning facilities should also be useful when planting is not possible. This zone is significant for the preservation of endangered fish species other than $B$. lenok, such as $K$. naktongensis, in this area. Therefore, part of the Nakdong River and Songjeongri stream area should be evaluated as an ecology protection area.

The flow of fertilizer and agricultural pesticides from farm lands into the sanctuary area should be terminated because the land is located close to streams, and trees around farmlands are lumbered as they interfere with farming. Therefore, $20 \mathrm{~m}$ of stream should be set up as a habitat transition zone and cultivation of crops should be restricted. The demise of fisheries due to accidents, such as toxic material spills due to overturned tank trucks or refinery leaks, have been reported. A particular concern was the finding of no pools deeper than 2-3 $\mathrm{m}$ in the Byeongo stream.

\section{Conclusions}

The purpose of this research was to evaluate the population and status of $B$. lenok tsinlingensis in the Bonghwa protective habitat, designated as Korean national monument number 74 . The biological composition of the environment, the body lengths of $B$. lenok individuals, and the fish distributions were investigated in the sanctuary zone. The water condition of neighboring streams in Bonghwa-gun were also evaluated in this research.

i) The Bonghwa cultural properties zone were identified as a habitat for B. lenok; however, this species was absent at the branch of the Sonjeongri stream, perhaps due to bank protection construction implemented in 2015. Fish collected in this zone were from 9 families and 19 species and included 7,509 individuals. The dominant species were $Z$. koreanus (R.A, 51.96\%) R. oxycephalus (R.A, 35.98\%), and B. lenok (R.A, 5.71\%). No B. lenok were over $400 \mathrm{~mm}$ in length, and most $B$. lenok collected were 0 to 2 years of age.

ii) $K$. naktongensis, a first grade endangered species of wild fauna in Korea, was found in the research stream. This water zone is a biologically and geologically valuable habitat for $K$. naktongensis as well as for $B$. lenok. Thirteen endemic Korean species were found, such as $C$. splendidus and $M$. yaluensis; the percentage of endemic species was $68.4 \%$. iii) Benthic macroinvertebrates in the research area were from four divisions, four classes, seven orders, 30 families, and 60 species and included 10,344 individuals. The main prey sources were Ephemeroptera (55.9\%), Plecoptera (2.1\%), and Trichoptera (12.4\%) (EPT); these EPT accounted $70.4 \%$ of the total and are associated with uncontaminated water systems. Ecosystem health status was assessed as highest through fine by the BMI (except Stations 5). However, it was graded as normal by BMI at Station 5.

iv) The water quality in this zone was considered clean and suitable for the growth of $B$. lenok. However, a water temperature increase up to $20^{\circ} \mathrm{C}$ in the summer at the Songjeongri stream. Methods such as pool restoration and designation of habitat buffer zones could be considered for maintenance of the $B$. lenok populations.

\section{Acknowledgments}

This study was supported by Grant from the Korea Rural Community Corporation.

\section{References}

1. Cheng Q, Zhen B. Systematic synopsis of Chinese fishes. Beijing: Science Press; 1987.

2. Li S. Discussion on the geographical distribution of the salmonid fishes in China. Chinese J. Zool. 1984;1:34-37.

3. Zhao Y, Zhang C. Threatened fishes of the world: Brachymystax lenok tsinlingensis Li, 1966 (Salmonidae). Environ. Biol. Fish. 2009;86:11-12.

4. NIER. Nationwide aquatic ecological monitoring program. Incheon: National institute of environmental research; 2013.

5. Jean SR. Revision of scientific name of the manchurian trout, Brachymystax lenok (Pisces; Salmonidae) from Han river, Korea. Korean J. Limnol. 1987;20:113-116.

6. Byeon HK. The characteristic of fish fauna and Brachimystax lenok tsinlingensis individuals in the Bonghwa-gun, Korea. Korean J. Environ. Ecol. 2011;25:876-886.

7. Yoon JD, Jang MH. Migration patterns of Brachymystax lenok tsinlinggensis using radio tags in the upper part of the Nakdong River. Korean J. Limnol. 2009;42:58-66.

8. Choi KC, Jeon SR, Kim IS, Son YM. Colored illustrations of the freshwater fishes of Korea, Seoul: Hyangmun publishing; 2002.

9. Uchida K. The fishes of Tyosen (Korea). Part 1. Nematognathi and Eventognathi. Bull. Fish. Exp. Stn. Govern. Gen. Tyosen 1939;6:1-458.

10. Chyung MK. The fishes of Korea. Seoul: Ilji publishing; 1977.

11. Kim IS. Illustrated encyclopedia of fauna and flora of Korea-freshwater fishes. Seoul: Ministry of Education; 1997.

12. Kim IS, Park JY. Freshwater fishes of Korea. Seoul: Kyohak publishing; 2002.

13. Kim IS, Choi Y, Lee CL, et al. Illustrated book of Korean fishes. Seoul: Kyohak publishing; 2005.

14. Nelson JS. Fishes of the world. New Jersey: John Wiley \& Sons; 2006. 
15. Margalef R. Information theory in ecology. Gen. Syst. 1958;3: 36-71.

16. Mcnaughton SJ, Anderson RO, Gutreuter SJ. Length weight and associated structural indices, in fisheries techniques. Nielsen LA, Johnson DL, eds. Bethesda: American Fisheries Society; 1983.

18. Pielou EC. Shannon's formula as a measure of specific diversity: Its use and misuse. Am. Nat. 1966;100:463-465.
19. Busacker GP, Adelman IA, Goolish EM. Methods for fish biology. Bethesda: American Fisheries Society: 1990.

20. Ministry of Environment in Korea. Survey of the national natural environment. Sejong: 2014.

21. Seo JW. Fish fauna and ecological characteristics of dark chub (Zacco temminkii) population in the mid-upper region of Gam stream. Korean J. Limnol. 2005;38:192-206. 